\title{
Progression of Changes in Dopamine Transporter Binding Site Density as a Result of Cocaine Self-Administration in Rhesus Monkeys
}

\author{
Sharon R. Letchworth, Michael A. Nader, Hilary R. Smith, David P. Friedman, and Linda J. Porrino \\ Center for the Neurobiological Investigation of Drug Abuse, Department of Physiology and Pharmacology, Wake Forest \\ University School of Medicine, Winston-Salem, North Carolina 27157
}

\begin{abstract}
The present study examined the time course of alterations in levels of dopamine transporter (DAT) binding sites that accompany cocaine self-administration using quantitative in vitro receptor autoradiography with $\left[{ }^{3} \mathrm{H}\right] \mathrm{WIN} 35,428$. The density of dopamine transporter binding sites in the striatum of rhesus monkeys with $5 \mathrm{~d}, 3.3$ months, or 1.5 years of cocaine selfadministration experience was compared with DAT levels in cocaine-naïve control monkeys. Animals in the long-term (1.5 years) exposure group self-administered cocaine at $0.03 \mathrm{mg} / \mathrm{kg}$ per injection, whereas the initial (5 d) and chronic (3.3 months) treatment groups were each divided into lower dose $(0.03$ $\mathrm{mg} / \mathrm{kg}$ per injection) and higher dose $(0.3 \mathrm{mg} / \mathrm{kg}$ per injection) groups. Initial cocaine exposure led to moderate decreases in $\left[{ }^{3} \mathrm{H}\right]$ WIN 35,428 binding sites, with significant changes in the dorsolateral caudate $(-25 \%)$ and central putamen $(-19 \%)$ at the lower dose. Longer exposure, in contrast, resulted in elevated levels of striatal binding sites. The increases were most pronounced in the ventral striatum at the level of the nucleus accumbens shell. At the lower dose of the chronic phase, for
\end{abstract}

Cocaine, a powerful psychomotor stimulant, is one of the most reinforcing drugs of abuse known. Although cocaine acts on dopamine, serotonin, and norepinephrine systems (Ritz et al., 1990), the dopamine system has long been implicated in the behavioral effects of cocaine (De Wit and Wise, 1977; Roberts et al., 1980; Goeders and Smith, 1983; Ritz et al., 1987; Spealman et al., 1989; Giros et al., 1996; Volkow et al., 1997). Cocaine exerts many of its actions in dopamine terminal fields, such as the nucleus accumbens and corpus striatum, by binding to the dopamine transporter (DAT) and blocking the reuptake of dopamine into presynaptic terminals (Ross and Renyi, 1967; Koe, 1976; Kennedy and Hanbauer, 1983). Because cocaine acts directly on DAT, researchers have hypothesized that DAT may be altered by repeated exposure to cocaine.

Such alterations have been examined within the brains of cocaine addicts using in vitro ligand binding in postmortem tissue, as well as in vivo imaging methods. Data concerning changes in

\footnotetext{
Received Oct. 2, 2000; revised Jan. 24, 2001; accepted Jan. 26, 2001.

This work was supported by United States Public Health Service Grants DA9085 and DA6634 from the National Institute on Drug Abuse. We thank Susan Nader, Clifford Hubbard, Tonya Moore, Hannah Harris, Drake Morgan, Joshua Lile, Rachna Sinnott, Osric Prioleau, Sherry Vinsant, and Rodney Moore for assistance in conducting these experiments.

Correspondence should be addressed to Dr. Linda J. Porrino, Department of Physiology and Pharmacology, Wake Forest University School of Medicine, Medical Center Boulevard, Winston-Salem, NC 27157. E-mail: lporrino@wfubmc.edu.

Copyright (C) 2001 Society for Neuroscience $0270-6474 / 01 / 212799-09 \$ 15.00 / 0$
}

example, significant increases of $21-42 \%$ were measured at the caudal level of the ventral caudate, ventral putamen, olfactory tubercle, and accumbens core and shell. Systematic variation of cocaine dose and drug exposure time demonstrated the importance of these factors in determining the intensity of increased DAT levels. With self-administration of higher doses especially, increases were more intense and included dorsal portions of the striatum so that every region at the caudal level exhibited a significant increase in DAT binding sites (20-54\%). The similarity of these findings to previous studies in human cocaine addicts strongly suggest that the increased density of dopamine transporters observed in studies of human drug abusers are the result of the neurobiological effects of cocaine, ruling out confounds such as polydrug abuse, preexisting differences in DAT levels, or comorbid psychiatric conditions.

Key words: cocaine; dopamine transporter; striatum; nucleus accumbens; self-administration; $\left[{ }^{3} H\right] W I N \quad 35,428$; rhesus monkeys

human DAT binding site levels, however, have been conflicting. Although the majority of studies have reported increases (Little et al., 1993, 1998a,b, 1999; Staley et al., 1994b; Malison et al., 1998), some studies have documented decreases (Hurd and Herkenham, 1993) or no change in DAT binding levels (Wilson et al., 1996). Interpretation of data from human studies can be complex, however. Differences in subject selection criteria, the presence of psychiatric disorders and polydrug abuse, wide disparities in length of drug use, and ligand used to label DAT can all influence the final outcome. In addition, incomplete documentation of drug histories can make it challenging to determine the relationship between the amount of cocaine consumed and changes in DAT binding levels in cocaine abusers. It has, therefore, been difficult to discern the exact nature of the effects of cocaine exposure on DAT binding site density in humans.

Rodent models of cocaine exposure have been used to overcome many of these problems. However, there are also conflicting reports of changes in rat DAT binding site regulation as a result of chronic cocaine administration. Cocaine exposure has been reported to increase (Alburges et al., 1993; Wilson et al., 1994a; Claye et al., 1995; Hitri et al., 1996; Tella et al., 1996), decrease (Sharpe et al., 1991; Pilotte et al., 1994, 1996; Wilson et al., 1994a; Boulay et al., 1996), or have no effect (Allard et al., 1990; Kula and Baldessarini, 1991; Benmansour et al., 1992; Cass et al., 1993; Wilson et al., 1994b; Kunko et al., 1997; Letchworth et al., 1997, 1999 ) on the density of rat DAT binding sites. Paradigm differ- 
ences such as drug dose, length and route of administration, time since the final drug administration, and ligand used to identify DAT may account for the variability among these studies.

Nonhuman primate models of cocaine self-administration offer another alternative. A significant advantage of this model is that the connectivity and structural complexity of the monkey brain are more homologous to the human brain. The only previous monkey study examining changes in DAT levels associated with cocaine exposure used a paradigm that consisted of $14 \mathrm{~d}$ of cocaine treatment, which resulted in significantly lower levels of DAT binding sites in the caudate (Farfel et al., 1992). This study has limitations because it used only a single dose of cocaine, did not examine changes in DAT levels over time, used noncontingent drug administration, and incorporated a significant drug withdrawal period.

The purpose of the present study, therefore, was to examine the initial (5 d), chronic (3.3 months), and long-term (1.5 years) phases of cocaine self-administration on DAT binding sites in rhesus monkeys who had no other exposure to experimental drugs. Within these time points, two cocaine doses were examined: 0.03 and $0.3 \mathrm{mg} / \mathrm{kg}$ per injection. These monkeys had no abstinence period after the last cocaine exposure, making them comparable with human subjects who test positive for cocaine at death. Such unique experimental conditions allow examination of the temporal progression of changes in DAT binding sites that result from cocaine self-administration.

$\left[{ }^{3} \mathrm{H}\right]$ WIN 35,428 specifically was chosen to label DAT because it occupies the same site on the DAT as cocaine (Kaufman et al., 1991) and because it has been shown to be a more accurate measure of dopamine terminals than the structurally unrelated [ $\left.{ }^{3} \mathrm{H}\right] \mathrm{GBR} 12,935$ (Soucy et al., 1997). It has been suggested that quantitative autoradiography, compared with ligand binding in tissue homogenates, may underestimate the magnitude of changes as a result of cocaine exposure (Staley et al., 1994b). However, the autoradiographic approach allows a detailed analysis of the topography of the distribution of these differences and identification of changes restricted to small brain regions.

\section{MATERIALS AND METHODS}

\section{Subjects}

Twenty-five adult male rhesus monkeys (Macaca mulatta) served as subjects. Monkeys were 6-13 years old at the start of the experiment and weighed between 7.5 and $13.0 \mathrm{~kg}$ under free-feeding conditions. Their body weights were maintained at $\sim 90-95 \%$ of free-feeding weights. Intravenous catheters and vascular access ports for drug delivery were implanted into a major vein as described previously (Nader and Reboussin, 1994; Nader and Bowen, 1995). All procedures were performed in accordance with established practices as described in the National Institutes of Health Guide for Care and Use of Laboratory Animals. In addition, all protocols were reviewed and approved by the Animal Care and Use Committee of Wake Forest University.

\section{Self-administration}

Initial and chronic exposure groups. Twenty-two monkeys were initially trained to respond under the fixed interval (FI) 3 min schedule of food presentation until stable performance was obtained. When foodmaintained responding was stable, indwelling intravenous catheters were implanted in all monkeys. Control monkeys $(n=6)$ continued to respond under the FI 3 min schedule of food presentation for the remainder of the study.

For the cocaine monkeys, drug self-administration under the FI 3 min schedule was established for four groups ( $n=4$ per group) by substituting cocaine for food presentation. The cocaine groups differed according to length of cocaine exposure [ 5 or $100 \mathrm{~d}$ (3.3 months)] and cocaine dose ( 0.03 or $0.3 \mathrm{mg} / \mathrm{kg}$ cocaine per injection). The $5 \mathrm{~d}$ duration was chosen for the initial phase to ensure that the monkeys had acquired drug self-administration. Furthermore, the $0.03 \mathrm{mg} / \mathrm{kg}$ per injection dose was chosen because it has been shown to maintain peak rates of responding under this schedule (Nader and Reboussin, 1994). The higher dose was selected as one $\log$ unit greater than the $0.03 \mathrm{mg} / \mathrm{kg}$ per injection dose and clearly represents a dose with greater reinforcing efficacy (Iglauer and Woods, 1974). For the safety of the monkeys, the final dose of 0.3 $\mathrm{mg} / \mathrm{kg}$ per injection was gradually introduced so that it followed two sessions of $0.1 \mathrm{mg} / \mathrm{kg}$ per injection and one session of $0.2 \mathrm{mg} / \mathrm{kg}$ cocaine per injection. All sessions ended after 30 reinforcer presentations. Total daily cocaine intake per session was $0.9 \mathrm{mg} / \mathrm{kg}$ for the low-dose monkeys and $9.0 \mathrm{mg} / \mathrm{kg}$ for the high-dose groups. Experimental sessions were conducted $7 \mathrm{~d} /$ week at approximately the same time each day. Total lifetime intake of cocaine was $4.5 \mathrm{mg} / \mathrm{kg}$ for the initial phase low-dose group, $45 \mathrm{mg} / \mathrm{kg}$ for the initial phase high-dose group, $90 \mathrm{mg} / \mathrm{kg}$ for the chronic phase low-dose group, and $900 \mathrm{mg} / \mathrm{kg}$ for the chronic phase high-dose group.

Long-term exposure group. Three monkeys responded under an FI 5 min schedule of $0.03 \mathrm{mg} / \mathrm{kg}$ cocaine per injection, during daily $4 \mathrm{hr}$ sessions. Experimental sessions were conducted 5-7 d/week. The maximum number of injections available per session was 45 (averaging 1.35 $\mathrm{mg} / \mathrm{kg}$ per session), and lifetime drug intake of $431-588 \mathrm{mg} / \mathrm{kg}$ cocaine was administered over a period of 18-22 months (1.5 years). In the final session, each monkey self-administered one injection of $1.0 \mathrm{mg} / \mathrm{kg}$ cocaine per injection, available under the FI 5 min schedule. Behavioral data from the long-term cocaine self-administration group is detailed in other reports (Nader and Reboussin, 1994; Nader and Bowen, 1995).

The three subjects used as controls for the long-term group ranged in age from 3.4 to 4.3 years. They were part of another study concerning the effects of a high-cholesterol diet on atherogenesis and the effects of phytoestrogens on lipid profiles. These animals had no experimental histories involving food or drug self-administration. Their only drug exposure occurred in the course of normal veterinary care.

\section{Tissue processing}

All monkeys except the controls for the long-term group were used for $2-\left[{ }^{14} \mathrm{C}\right]$ deoxyglucose $(2-\mathrm{DG})$ analysis. The 2 -DG experiment was initiated subsequent to the last cocaine inf usion, involved sampling of arterial blood, and lasted $\sim 45 \mathrm{~min}$. Immediately after the $2-\mathrm{DG}$ procedure, animals were killed with sodium pentobarbital (100 mg/kg, i.v.). Controls for the long-term cocaine self-administration experiment were anesthetized with ketamine $(10 \mathrm{mg} / \mathrm{kg}$, i.m.) and then given a lethal overdose of sodium pentobarbital.

For all animals, brains were immediately removed, blocked, and frozen in isopentane at $35-55^{\circ} \mathrm{C}$ and then stored at $-80^{\circ} \mathrm{C}$. Coronal sections $(20$ $\mu \mathrm{m})$ were cut on a cryostat, thaw-mounted onto chrome-alum-gelatinsubbed slides or electrostatically charged slides, desiccated, and stored at $-80^{\circ} \mathrm{C}$ until processed for quantitative autoradiography.

\section{Quantitative autoradiography}

For $\left[{ }^{3} \mathrm{H}\right]$ WIN 35,428 autoradiography, single-point binding assays were conducted at $\sim 1.5$ times the $K_{\mathrm{D}}(3.6 \mathrm{nM})$ as determined in monkey tissue sections by Canfield et al. (1990). Procedures for the current study were adapted from the same paper. Tissue sections were preincubated at $4^{\circ} \mathrm{C}$ in buffer (50 mM Tris and $100 \mathrm{~mm} \mathrm{NaCl}, \mathrm{pH} 7.4)$ for $20 \mathrm{~min}$ to remove any residual cocaine and $2-\left[{ }^{14} \mathrm{C}\right]$ deoxyglucose. Sections were then incubated for $1-2 \mathrm{hr}$ at $4{ }^{\circ} \mathrm{C}$ in buffer containing $5 \mathrm{~nm}\left[{ }^{3} \mathrm{H}\right]$ W IN 35,428 (84.5 $\mathrm{Ci} / \mathrm{mmol}$ ) (NEN, Boston, MA) in the presence (nonspecific binding) or absence (total binding) of $1 \mu \mathrm{M}$ cocaine. Sections were then rinsed for a total of $2 \mathrm{~min}$ in buffer at $4^{\circ} \mathrm{C}$, with a final $10 \mathrm{sec}$ rinse in ice-cold water. Sections were immediately dried under a stream of cold air and placed on Hyperfilm- ${ }^{3} \mathrm{H}$ (Amersham Pharmacia Biotech, Arlington Heights, IL) for 4-6 weeks in the presence of $\left[{ }^{3} \mathrm{H}\right]$ standards (Amersham Pharmacia Biotech). After appropriate exposure times, films were developed with Kodak GBX developer (Eastman Kodak, Rochester, NY), fixed, and rinsed.

\section{Densitometry}

Autoradiographic analysis of $\left[{ }^{3} \mathrm{H}\right]$ WIN 35,428 binding to DAT was conducted by quantitative densitometry with a computerized image processing system (MCID; Imaging Research Inc., St. Catharines, Ontario, Canada). Optical density measurements of DAT binding sites were measured in selected divisions of the caudate, putamen, and nucleus accumbens rostral to the anterior commissure. This region has been designated the precommissural striatum (PCS). Specifically, rostral and caudal levels of the PCS were designated in relation to the nucleus 
A
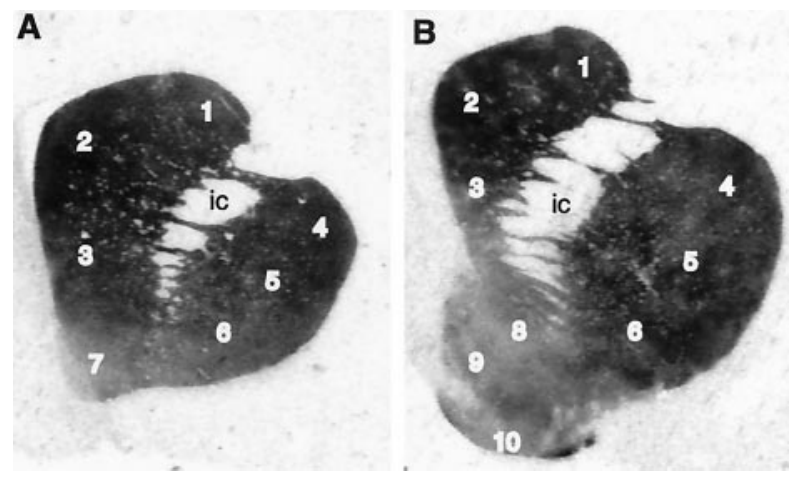

Figure 1. Autoradiograms of $\left[{ }^{3} \mathrm{H}\right]$ WIN 35,428 binding in coronal sections from brains of rhesus (Macaca mulatta) monkeys. Measurements were taken at two levels in the striatum, the rostral PCS $(A)$ and the caudal PCS ( $B)$, as described in Materials and Methods. Numbers correspond to striatal regions as follows: 1 , dorsolateral caudate; 2 , dorsomedial caudate; 3 , ventral caudate; 4 , dorsal putamen; 5 , central putamen; 6 , ventral putamen; 7 , rostral accumbens; 8 , accumbens core; 9 , accumbens shell; 10 , olfactory tubercle.

accumbens and anterior commissure as illustrated in Figure 1. The rostral level, in which the accumbens was not differentiated into distinct shell and core subcompartments, was defined as the rostral PCS. The caudal PCS was the region posterior to the emergence of the olfactory tubercle (which was congruent with the appearance of the shell and core of the nucleus accumbens) but rostral to the decussation of the anterior commissure.

Once optical densities were measured, tissue equivalent values (femtomoles per milligram of wet weight tissue) were determined from the optical densities and from a calibration curve obtained by densitometric analysis of tritium standards. Specific binding was determined by subtracting nonspecific binding values from the total binding values, measured in adjacent sections.

\section{Statistical analysis}

Analysis of control data from initial and chronic studies revealed no significant differences in striatal DAT binding densities. These groups were combined, which permitted limiting the overall number of animals studied across conditions. The pooled control group was compared with each dose of the initial $(5 \mathrm{~d})$ and chronic ( 3.3 months) cocaine selfadministering monkeys. Statistical analysis was performed for every brain structure by means of a one-way ANOVA, followed by multiple comparisons [least significant difference (LSD)] comparing drug treatments to the pooled controls.

The long-term exposure group (1.5 years) was treated as a separate experiment because of differences in experimental technique. Thus, the control animals from the long-term group were not included with the pooled initial and chronic controls, although values from these groups were not statistically different from each other. For the long-term group, autoradiographic data from each brain region were analyzed by means of Student's two-tailed $t$ test for independent samples.

\section{RESULTS}

\section{Controls}

The binding pattern of $\left[{ }^{3} \mathrm{H}\right] \mathrm{WIN} 35,428$ to DAT in tissue sections from control animals was consistent with previous reports of the distribution of DAT binding sites in monkey and human brain (Canfield et al., 1990; Kaufman et al., 1991; Staley et al., 1994a; De La Garza et al., 1999). Binding sites were prominent within the dorsal and ventral striatum and near background in the surrounding gray and white matter (Fig. 1). Furthermore, nonspecific binding was minimal ( $<10 \%$ of total binding).

DAT binding sites were heterogeneously distributed in a regional manner within the striatum (Fig. 1; see Fig. 4, Control). The dorsal portions of both the caudate and the putamen exhibited the highest binding densities, whereas ventral striatal regions, including the nucleus accumbens, displayed lower binding densities. These differences appeared as a gradient from dorsal regions to ventral regions. In addition, small regions of lower binding were observed in the dorsomedial and ventral caudate, suggestive of the striosomes observed in monkey striatum by Graybiel and Moratalla (1989). No significant rostrocaudal gradient in DAT binding site density was observed in the caudate or putamen.

Within the accumbens, further heterogeneities were evident. At the level of the rostral PCS (Fig. $1 A$ ), the dorsoventral striatal gradient continued into the accumbens. Caudal to the emergence of the olfactory tubercle, the shell and core divisions of the nucleus accumbens were clearly defined (Fig. 1B), with the core exhibiting higher DAT binding levels than the adjacent shell. At this caudal PCS level, the shell contained aggregations of very dense binding, which extended laterally toward the ventral putamen. These clusters contained approximately twice the density of DAT binding sites than the surrounding accumbens shell (Fig. 1; see Fig. 4, Control).

\section{Effects of cocaine self-administration}

The general pattern of $\left[{ }^{3} \mathrm{H}\right]$ W IN 35,428 binding in cocaine selfadministering monkeys was similar to that of controls. There were, however, regional differences in binding site densities between the control and cocaine groups.

\section{Initial phase}

Five days of cocaine self-administration resulted in decreases in DAT binding site density compared with controls, which are shown in Table 1 . At the lower dose $(0.03 \mathrm{mg} / \mathrm{kg}$ per injection $)$ (Fig. 2, top row), a trend of global decreases was observed at both rostral and caudal levels and ranged from 15 to $25 \%$ in the rostral PCS regions, whereas $11-25 \%$ decreases were measured in caudal PCS regions. Within this group, significant effects $(p<0.05)$ were seen in the rostral and caudal dorsolateral caudate and in the caudal central putamen. At the higher dose $(0.3 \mathrm{mg} / \mathrm{kg}$ per injection), decreases were not as robust as those measured at the lower dose and were not significant in any region examined.

\section{Chronic phase}

\section{Lower cocaine dose}

In contrast to the decreases observed in the initial phases, the effects of 3.3 months of cocaine self-administration were characterized by increases in the concentration of $\left[{ }^{3} \mathrm{H}\right]$ W IN 35,428 binding sites (Table 2; Fig. 2, middle row). These increases were both dose-dependent and regionally specific. Exposure to selfadministration of the lower dose of cocaine for 3.3 months produced significant increases in DAT binding site density in the nucleus accumbens $(30 \% ; p<0.05)$ at the level of rostral PCS. In the caudal PCS, significant increases were restricted to ventral striatal territories and included the nucleus accumbens core $(37 \% ; p<0.01)$ and shell $(31 \% ; p<0.05)$, as well as the ventral caudate $(21 \% ; p<0.05)$, ventral putamen $(26 \% ; p<0.05)$, and olfactory tubercle $(42 \% ; p<0.01)$.

\section{Higher cocaine dose}

Exposure to the higher dose $(0.3 \mathrm{mg} / \mathrm{kg}$ per injection) resulted in greater increases that involved a wider expanse of the striatum when compared with data from the lower cocaine dose of the same phase (Fig. 3). Increases in DAT binding densities were greatest in the ventral striatal regions (Table 2; Fig. 3, right panel). Specifically, in the caudal PCS, significant increases in binding site density, which were the largest observed in this study, were found in the ventral caudate $(25 \% ; p<0.01)$, ventral putamen 


\begin{tabular}{|c|c|c|c|c|c|}
\hline Brain regions & $\begin{array}{l}\text { Control } \\
n=6\end{array}$ & $\begin{array}{l}\text { Cocaine } \\
0.03 \mathrm{mg} / \mathrm{kg} / \mathrm{inj} \\
n=4\end{array}$ & $\begin{array}{l}\text { Percent } \\
\text { difference }^{b}\end{array}$ & $\begin{array}{l}\text { Cocaine } \\
0.3 \mathrm{mg} / \mathrm{kg} / \mathrm{inj} \\
n=4\end{array}$ & $\begin{array}{l}\text { Percent } \\
\text { difference }^{b}\end{array}$ \\
\hline \multicolumn{6}{|c|}{ Rostral precommissural striatum } \\
\hline Dorsolateral caudate & $95.1 \pm 9$ & $71.6 \pm 5^{*}$ & $25 \%$ & $79.0 \pm 4$ & $17 \%$ \\
\hline Dorsomedial caudate & $116.4 \pm 9$ & $99.6 \pm 6$ & $15 \%$ & $98.5 \pm 6$ & $15 \%$ \\
\hline Ventral caudate & $107.3 \pm 8$ & $89.5 \pm 3$ & $17 \%$ & $88.1 \pm 7$ & $18 \%$ \\
\hline Dorsal putamen & $116.1 \pm 9$ & $93.2 \pm 7$ & $20 \%$ & $104.7 \pm 9$ & $10 \%$ \\
\hline Central putamen & $107.2 \pm 7$ & $90.7 \pm 7$ & $15 \%$ & $96.9 \pm 3$ & $10 \%$ \\
\hline Ventral putamen & $85.1 \pm 8$ & $70.8 \pm 8$ & $17 \%$ & $77.5 \pm 4$ & $9 \%$ \\
\hline Accumbens & $56.6 \pm 5$ & $45.4 \pm 4$ & $20 \%$ & $47.7 \pm 5$ & $16 \%$ \\
\hline \multicolumn{6}{|c|}{ Caudal precommissural striatum } \\
\hline Dorsolateral caudate & $96.7 \pm 7$ & $72.1 \pm 4^{*}$ & $25 \%$ & $85.6 \pm 10$ & $12 \%$ \\
\hline Dorsomedial caudate & $120.8 \pm 6$ & $103.2 \pm 6$ & $15 \%$ & $113.6 \pm 11$ & $6 \%$ \\
\hline Ventral caudate & $88.9 \pm 3$ & $78.8 \pm 7$ & $11 \%$ & $82.9 \pm 6$ & $7 \%$ \\
\hline Dorsal putamen & $110.5 \pm 2$ & $91.4 \pm 4$ & $17 \%$ & $106.2 \pm 13$ & $4 \%$ \\
\hline Central putamen & $105.3 \pm 3$ & $85.5 \pm 6^{*}$ & $19 \%$ & $100.3 \pm 1$ & $5 \%$ \\
\hline Ventral putamen & $88.5 \pm 6$ & $70.9 \pm 7$ & $20 \%$ & $78.0 \pm 9$ & $12 \%$ \\
\hline Accumbens (shell) & $48.6 \pm 5$ & $38.4 \pm 4$ & $21 \%$ & $45.9 \pm 9$ & $6 \%$ \\
\hline Accumbens (core) & $59.4 \pm 4$ & $49.5 \pm 3$ & $17 \%$ & $54.1 \pm 7$ & $9 \%$ \\
\hline Olfactory tubercle & $58.3 \pm 4$ & $48.6 \pm 6$ & $17 \%$ & $53.4 \pm 8$ & $8 \%$ \\
\hline
\end{tabular}

\footnotetext{
${ }^{a}$ Data represent femtomoles per milligram, wet weight tissue and are expressed as mean \pm SEM.

${ }^{b}$ Percent difference from control values.

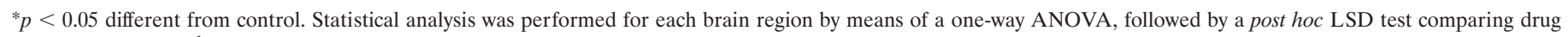
treatments to controls.
}

inj, Injection.

(29\%; $p<0.05)$, accumbens shell (54\%; $p<0.005)$, accumbens core $(46 \% ; p<0.005)$, and olfactory tubercle $(38 \% ; p<0.005)$. In contrast to the effects of the lower dose, large increases in DAT binding sites also occurred in dorsal regions of the caudal PCS level after self-administration of the higher dose of cocaine, so that every brain region at this caudal level exhibited significant increases in the concentration of DAT binding sites. This included the dorsolateral caudate $(25 \% ; p<0.05)$, dorsomedial caudate $(20 \% ; p<0.05)$, dorsal putamen $(31 \% ; p<0.005)$, and central putamen $(28 \% ; p<0.05)$.

At both cocaine doses in the chronic phase of selfadministration, the majority of significant increases in DAT binding site density occurred at the level of the caudal PCS. This difference between the rostral and caudal PCS was especially apparent at the higher cocaine dose, in which large, significant increases in DAT sites were measured in every caudal PCS region, but no significant change was detected at rostral levels.

\section{Long-term phase}

An additional series of animals that had self-administered 0.03 $\mathrm{mg} / \mathrm{kg}$ cocaine per injection for $18-22$ months (1.5 years) was examined. The data from these animals are presented in Table 3 and illustrated in Figures 2 (bottom row) and 4 (Cocaine). In general, the increases in $\left[{ }^{3} \mathrm{H}\right] \mathrm{WIN} 35,428$ binding site density after long-term self-administration were greater than those seen after shorter durations of cocaine exposure at comparable doses.

Specifically, at the level of the rostral PCS, increases ranging from 16 to $33 \%$ were observed in the cocaine self-administering animals, although none of these differences reached statistical significance. At the level of the caudal PCS, however, long-term exposure to cocaine produced significant increases in the density of DAT binding sites in the ventral striatum. These included the ventral caudate $(44 \% ; p<0.005)$, the core of the nucleus accum- bens $(39 \% ; p<0.01)$, the shell of the nucleus accumbens $(15 \%$; $p<0.05)$, and the olfactory tubercle $(33 \% ; p<0.01)$. In the dorsal striatum at this level, moderate (15-30\%), although not significant, increases were observed.

\section{DISCUSSION}

The results of the present study demonstrate that cocaine selfadministration alters dopamine transporter binding and that these changes follow a clear progression over time. In the initial stages of cocaine self-administration (5 d), DAT binding site levels were moderately reduced, whereas after more prolonged cocaine self-administration (3.3 months), large increases in the density of DAT sites were evident. These increases in DAT binding levels persisted even after protracted periods of selfadministration (1.5 years). A key characteristic of the alterations in DAT binding was the dose-dependent nature of the effects. Chronic cocaine self-administration at the higher cocaine dose yielded more intense increases in the density of the DAT binding sites and encompassed a wider expanse of the caudal PCS than self-administration of the lower dose. Finally, the majority of significant changes in DAT binding density that occurred after chronic and long-term cocaine self-administration were focused in the ventral striatum, particularly at the level of the striatum in which the shell of the nucleus accumbens was present.

The data presented in this report confirm and extend the findings of studies in human cocaine users. The increases in DAT binding sites observed here after chronic and long-term cocaine self-administration in monkeys correspond closely to those increases reported in human cocaine addicts (Little et al., 1993, 1998a,b, 1999; Staley et al., 1994b; Malison et al., 1998) (but see Wilson et al., 1986; Hurd and Herkenham, 1993). Because human addicts frequently use and abuse multiple drugs and often have 


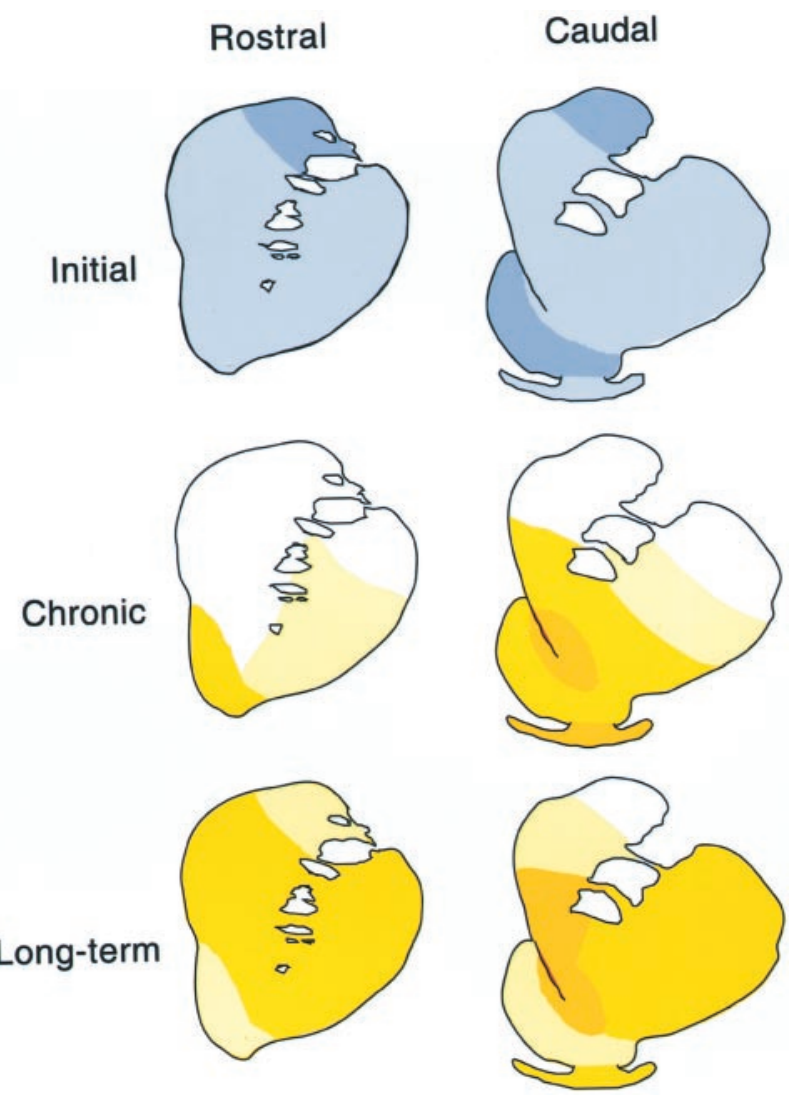

Figure 2. Time course of effects on DAT density in rhesus monkeys self-administering $0.03 \mathrm{mg} / \mathrm{kg}$ cocaine per injection. Schematic diagrams illustrate changes in the density of dopamine transporter binding sites at rostral (left column) and caudal (right column) levels of the PCS of monkeys in the initial (5 d), chronic (3.3 months), and long-term (1.5 years) stages of cocaine self-administration. Colors represent ranges of percent changes in binding densities compared with control values: light blue, 10-20\% decrease; medium blue, 21-35\% decrease; white, $<10 \%$ change; light yellow, 10-20\% increase; medium yellow, 21-35\% increase; dark yellow, $>35 \%$ increase. At initial stages of cocaine selfadministration, decreases in DAT levels were observed, whereas increases were measured at chronic and long-term stages. Increases in DAT density were first observed in the ventral striatum at the chronic stage, but spread to rostral and dorsal regions with longer durations of exposure.

psychiatric disorders that may have predated their cocaine use, changes in the density of the human DAT cannot be ascribed with confidence to the actions of cocaine alone. The present study, however, systematically examined the effects of cocaine dose and length of self-administration, while ruling out many of the factors that confound the human data.

One of the major caveats of the human drug abuse literature is the uncertainty whether the neurobiological differences between drug users and controls are attributable to a preexisting trait or are a secondary response to drug exposure (Malison et al., 1998). Because only a portion of the individuals who experiment with cocaine become addicts (Gawin, 1991), it is likely that these individuals have phenotypic differences, potentially differences in DAT binding site levels, that make them more susceptible to cocaine addiction. In the present study, however, the selection of monkeys for treatment was random and not based on their preference for the drug. Moreover, the fact that orderly effects of length of drug exposure and dose were observed in this study strongly suggests that the changes measured here are related to the neurobiological effects of cocaine rather than any preexisting difference in DAT binding density.

Despite polydrug abuse and potential comorbid psychiatric conditions, changes in human DAT binding site density are remarkably similar to the present findings, reconciling potential discrepancies in the human data. Increases in human DAT binding site density have been reported using cocaine analogs to radiolabel DAT with in vitro ligand binding in postmortem tissue as well as in vivo imaging methods. Although moderate increases in DAT binding density $(20-35 \%)$ have been reported in some studies (Little et al., 1998a; Malison et al., 1998), larger increases in human DAT binding density have been also been observed (Little et al., 1993, 1998b, 1999; Staley et al., 1994b). For example, Little et al. (1998b, 1999) reported 40-45\% increases in striatal $\left[{ }^{3} \mathrm{H}\right]$ WIN 35,428 binding sites in tissue sections from human cocaine users and $50 \%$ increases in binding sites in caudate putamen homogenates. These increases are of a comparable magnitude with those observed in the present study during the chronic and long-term stages of cocaine self-administration. Similar to the monkeys used in the present study, Little et al.'s human subjects all had recently used cocaine, with only $25 \%$ of their subjects having died from drug-related causes. In contrast, Staley and her colleagues (1994b) reported much larger elevations, with two fold to threefold increases in DAT binding sites evident in some striatal regions when compared with control brain tissue. All of the subjects in that study, however, were victims of a fatal cocaine overdose. Although the data from Little and colleagues (1998b), as well as the present data, indicate that cocaine overdose is not necessary for increases in DAT binding site density to occur, the overdose cases may represent a unique subset of cocaine users, which results in the larger increases in DAT binding density compared with controls.

In autoradiographic studies of DAT binding site levels in human cocaine users, elevations in DAT density have been observed throughout the dorsoventral extent of the striatum (Staley et al., 1994b; Little et al., 1998b), with the greatest increases evident in the ventral striatum (Staley et al., 1994b). This topography parallels the present results, particularly in those animals exposed chronically to the higher dose of cocaine. In this treatment group, every striatal region in the caudal PCS exhibited a significant increase in DAT binding sites, with the greatest increases occurring in the ventral striatum. By systematically varying both the dose and duration of exposure to cocaine self-administration, the present study was able to expand on the previous autoradiography studies in human cocaine users. The results demonstrate that, at lower cocaine doses in the chronic phase, only the ventral, limbicrelated portions of the striatum were affected. In contrast, higher doses were required for dorsal regions, associated with sensorimotor functions, to be recruited. Furthermore, with a longer duration of cocaine exposure, increases in both dorsal and rostral regions appear to be incorporated.

Another important dimension to the topography of elevated DAT binding densities associated with cocaine self-administration is the rostrocaudal level of the PCS. The most intense alterations in DAT binding site levels were most prominent within the caudal extent of the ventral striatum in which the shell of the nucleus accumbens is present. This distinction between rostral and caudal portions of the ventral striatum is also evident with other markers that have been examined in the same cohort of monkeys. For example, significant decreases in dopamine $\mathrm{D}_{1}$ receptor density were concentrated in caudal, as opposed to rostral, portions of the ventral striatum (Moore et al., 1998). Furthermore, changes in 


\begin{tabular}{|c|c|c|c|c|c|}
\hline Brain regions & $\begin{array}{l}\text { Control } \\
n=6\end{array}$ & $\begin{array}{l}\text { Cocaine } \\
0.03 \mathrm{mg} / \mathrm{kg} / \mathrm{inj} \\
n=4\end{array}$ & $\begin{array}{l}\text { Percent } \\
\text { difference }^{b}\end{array}$ & $\begin{array}{l}\text { Cocaine } \\
0.3 \mathrm{mg} / \mathrm{kg} / \mathrm{inj} \\
n=4\end{array}$ & $\begin{array}{l}\text { Percent } \\
\text { difference }\end{array}$ \\
\hline \multicolumn{6}{|c|}{ Rostral precommissural striatum } \\
\hline Dorsolateral caudate & $95.1 \pm 9$ & $91.6 \pm 8$ & $4 \%$ & $97.7 \pm 4$ & $3 \%$ \\
\hline Dorsomedial caudate & $116.4 \pm 9$ & $120.6 \pm 6$ & $4 \%$ & $124.1 \pm 10$ & $7 \%$ \\
\hline Ventral caudate & $107.3 \pm 8$ & $116.2 \pm 6$ & $8 \%$ & $112.8 \pm 6$ & $5 \%$ \\
\hline Dorsal putamen & $116.1 \pm 9$ & $121.4 \pm 11$ & $5 \%$ & $125.4 \pm 7$ & $8 \%$ \\
\hline Central putamen & $107.2 \pm 7$ & $121.1 \pm 9$ & $13 \%$ & $116.7 \pm 6$ & $9 \%$ \\
\hline Ventral putamen & $85.1 \pm 8$ & $101.8 \pm 5$ & $20 \%$ & $96.7 \pm 4$ & $14 \%$ \\
\hline Accumbens & $56.6 \pm 5$ & $73.4 \pm 5^{*}$ & $30 \%$ & $68.2 \pm 2$ & $20 \%$ \\
\hline \multicolumn{6}{|c|}{ Caudal precommissural striatum } \\
\hline Dorsolateral caudate & $96.7 \pm 7$ & $100.6 \pm 8$ & $4 \%$ & $120.7 \pm 5^{*}$ & $25 \%$ \\
\hline Dorsomedial caudate & $120.8 \pm 6$ & $131.8 \pm 7$ & $9 \%$ & $145.0 \pm 9^{*}$ & $20 \%$ \\
\hline Ventral caudate & $88.9 \pm 3$ & $107.2 \pm 8^{*}$ & $21 \%$ & $110.6 \pm 5^{* *}$ & $25 \%$ \\
\hline Dorsal putamen & $110.5 \pm 2$ & $120.2 \pm 10$ & $9 \%$ & $144.2 \pm 9^{* * *}$ & $31 \%$ \\
\hline Central putamen & $105.3 \pm 3$ & $125.6 \pm 11$ & $19 \%$ & $134.5 \pm 8^{*}$ & $28 \%$ \\
\hline Ventral putamen & $88.5 \pm 6$ & $111.2 \pm 8^{*}$ & $26 \%$ & $114.2 \pm 9^{*}$ & $29 \%$ \\
\hline Accumbens (shell) & $48.6 \pm 5$ & $63.7 \pm 3^{*}$ & $31 \%$ & $74.7 \pm 5^{* * *}$ & $54 \%$ \\
\hline Accumbens (core) & $59.4 \pm 4$ & $81.1 \pm 7^{* *}$ & $37 \%$ & $86.7 \pm 6^{* * *}$ & $46 \%$ \\
\hline Olfactory tubercle & $58.3 \pm 4$ & $82.6 \pm 1^{* *}$ & $42 \%$ & $80.4 \pm 1^{* * *}$ & $38 \%$ \\
\hline
\end{tabular}

\footnotetext{
${ }^{a}$ Data represent femtomoles per milligram, wet weight tissue and are expressed as mean \pm SEM.

${ }^{b}$ Percent difference from control values.

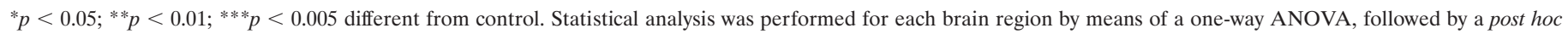
LSD test comparing drug treatments to controls.
}

inj, Injection.

functional activity, as assessed by the 2-[ $\left.{ }^{14} \mathrm{C}\right]$ deoxyglucose method, followed a similar topographical pattern with the largest alterations contained in the caudal ventral striatum at the level of the nucleus accumbens shell (Daunais et al., 1997).

The largest increases reported here were observed in portions of the striatum that contain the lowest basal DAT binding levels. Because cocaine binds to DAT to produce its effect, one might speculate that the greatest changes in DAT density would occur in regions that expressed the highest basal density of DAT levels, such as the dorsal striatum. In contrast, the increases in DAT binding sites measured in this study were not dependent on the regional density of DAT. Recent experiments on dopamine levels in primate brain as a result of stimulant administration shed light on this paradox. Elevations in extracellular dopamine were found to be greatest in the ventral striatum of baboons after acute, noncontingent amphetamine administration (Drevets et al., 1999). In a rhesus monkey model of recreational cocaine use (one cocaine self-administration session per week over the course of 3 months), the ventral striatum yielded greater elevations in extracellular dopamine compared with the central and dorsal striatum (Bradberry et al., 2000). These data suggest that changes in DAT density observed in the present study are related to local concentrations of extracellular dopamine that accumulate after cocaine exposure. After 6 months of "recreational" cocaine selfadministration in monkeys, Bradberry (2000) observed progressive increases in extracellular dopamine concentrations in the ventromedial and central striatum but not the dorsolateral striatum. These data correspond closely to the progression of increases in DAT binding site levels observed here in the lower dose groups at 3.3 months and 1.5 years (Fig. 2). In fact, the cocaine dose per session used in the 6 month study by Bradberry (2000) was very similar to the lower cocaine dose in this study. Based on the data presented here, it would be reasonable to assume that a higher cocaine dose, longer duration of exposure, or more frequent drug-taking sessions would result in elevated extracellular dopamine levels in the dorsolateral striatum.

The present results contain new information about the time course of cocaine-induced changes in DAT binding levels that are not apparent from studies in humans. First, robust cocaineinduced increases in DAT binding site density were already observed only 3 months after the initiation of cocaine use. This is much sooner than is apparent from the human literature, which

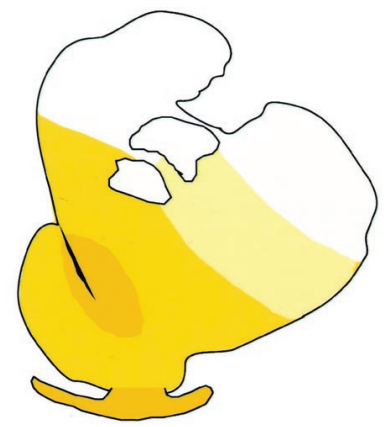

\section{$0.03 \mathrm{mg} / \mathrm{kg} / \mathrm{inj}$}

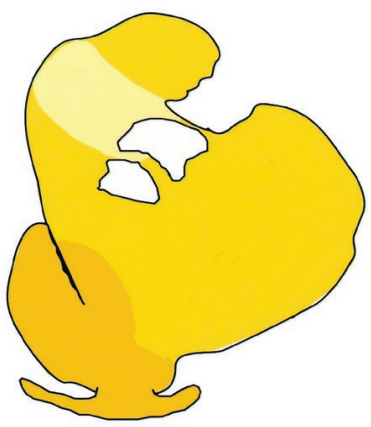

$0.3 \mathrm{mg} / \mathrm{kg} / \mathrm{inj}$
Figure 3. Dose-dependent changes in DAT density in rhesus monkeys after 3.3 months of cocaine self-administration. Schematic diagrams illustrate changes in the density of dopamine transporter binding sites at the caudal PCS level in rhesus monkeys after 3.3 months of selfadministration of 0.03 (left) and 0.3 (right) $\mathrm{mg} / \mathrm{kg}$ cocaine per injection. Colors represent ranges of percent changes in binding densities compared with control values: white, $<10 \%$ change; light yellow, 10-20\% increase; medium yellow, 21-35\% increase; dark yellow, $>35 \%$ increase. Greater increases were measured, and at this dose all dorsal striatal regions exhibited increases in DAT levels. 
Table 3. Striatal $\left[{ }^{3} \mathrm{H}\right]$ WIN 35,428 binding densities in monkeys during the long-term phase of cocaine self-administration ${ }^{a}$

\begin{tabular}{|c|c|c|c|}
\hline Brain regions & $\begin{array}{l}\text { Control } \\
n=3\end{array}$ & $\begin{array}{l}\text { Cocaine } \\
0.03 \mathrm{mg} / \mathrm{kg} / \mathrm{inj} \\
n=3\end{array}$ & $\begin{array}{l}\text { Percent } \\
\text { difference }^{b}\end{array}$ \\
\hline \multicolumn{4}{|c|}{ Rostral precommissural striatum } \\
\hline Dorsolateral caudate & $86.7 \pm 12$ & $102.6 \pm 12$ & $18 \%$ \\
\hline Dorsomedial caudate & $102.2 \pm 4$ & $124.9 \pm 12$ & $22 \%$ \\
\hline Ventral caudate & $90.0 \pm 10$ & $116.8 \pm 7$ & $30 \%$ \\
\hline Dorsal putamen & $110.9 \pm 13$ & $135.2 \pm 16$ & $22 \%$ \\
\hline Central putamen & $98.8 \pm 13$ & $131.4 \pm 10$ & $33 \%$ \\
\hline Ventral putamen & $85.4 \pm 8$ & $103.8 \pm 5$ & $21 \%$ \\
\hline Accumbens & $54.5 \pm 1$ & $63.3 \pm 8$ & $16 \%$ \\
\hline \multicolumn{4}{|c|}{ Caudal precommissural striatum } \\
\hline Dorsolateral caudate & $108.0 \pm 19$ & $110.7 \pm 8$ & $2 \%$ \\
\hline Dorsomedial caudate & $125.0 \pm 16$ & $144.2 \pm 13$ & $15 \%$ \\
\hline Ventral caudate & $86.0 \pm 6$ & $124.1 \pm 1^{* * *}$ & $44 \%$ \\
\hline Dorsal putamen & $114.3 \pm 16$ & $140.9 \pm 12$ & $23 \%$ \\
\hline Central putamen & $101.4 \pm 17$ & $131.9 \pm 5$ & $30 \%$ \\
\hline Ventral putamen & $83.9 \pm 11$ & $108.9 \pm 4$ & $30 \%$ \\
\hline Accumbens (shell) & $51.9 \pm 1$ & $59.7 \pm 3^{*}$ & $15 \%$ \\
\hline Accumbens (core) & $59.7 \pm 4$ & $83.2 \pm 3^{* *}$ & $39 \%$ \\
\hline Olfactory tubercle & $55.4 \pm 4$ & $73.4 \pm 2^{* *}$ & $33 \%$ \\
\hline
\end{tabular}

${ }^{a}$ Data represent femtomoles per milligram, wet weight tissue and are expressed as mean \pm SEM.

${ }^{b}$ Percent difference from control values.

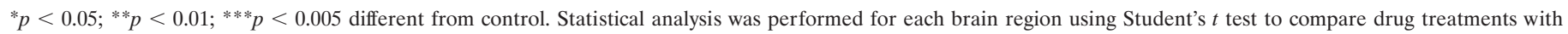
controls.

inj, Injection.

report findings on subjects who typically have years of experience with cocaine. Second, our monkeys self-administered cocaine on a highly regular basis, indicating that changes in human DAT binding site levels not only can occur rapidly, but can also occur with regular drug-taking patterns. Thus, the density changes reported in humans are unlikely to depend on the binge-crash pattern that is common among cocaine addicts. Third, we have supplied evidence that the effect of initial exposure to cocaine, which yielded moderate decreases in DAT binding site density, is different from the effect of long-term, repeated cocaine use, which yielded increases in DAT binding density. Because the shift from decreases to increases is occurring at some point between $5 \mathrm{~d}$ and
3.3 months, it is possible that some of the inconsistencies in the rat literature may be explained by the length of the experiments typically performed in rats. Cocaine exposure in these studies commonly occurs for 7-14 d, which may coincide with the time when the response of the DAT to cocaine is most labile, shifting from a downregulated to an upregulated condition.

It should be noted that increases in DAT binding sites may not reflect a corresponding increase in DAT protein (Staley et al., 1995; Wilson et al., 1996; Oakman et al., 2000). Although the basis of the discrepancy between DAT binding sites and protein levels is not clear at this point, the mechanisms of DAT regulation are just beginning to be elucidated. It is possible that increases in

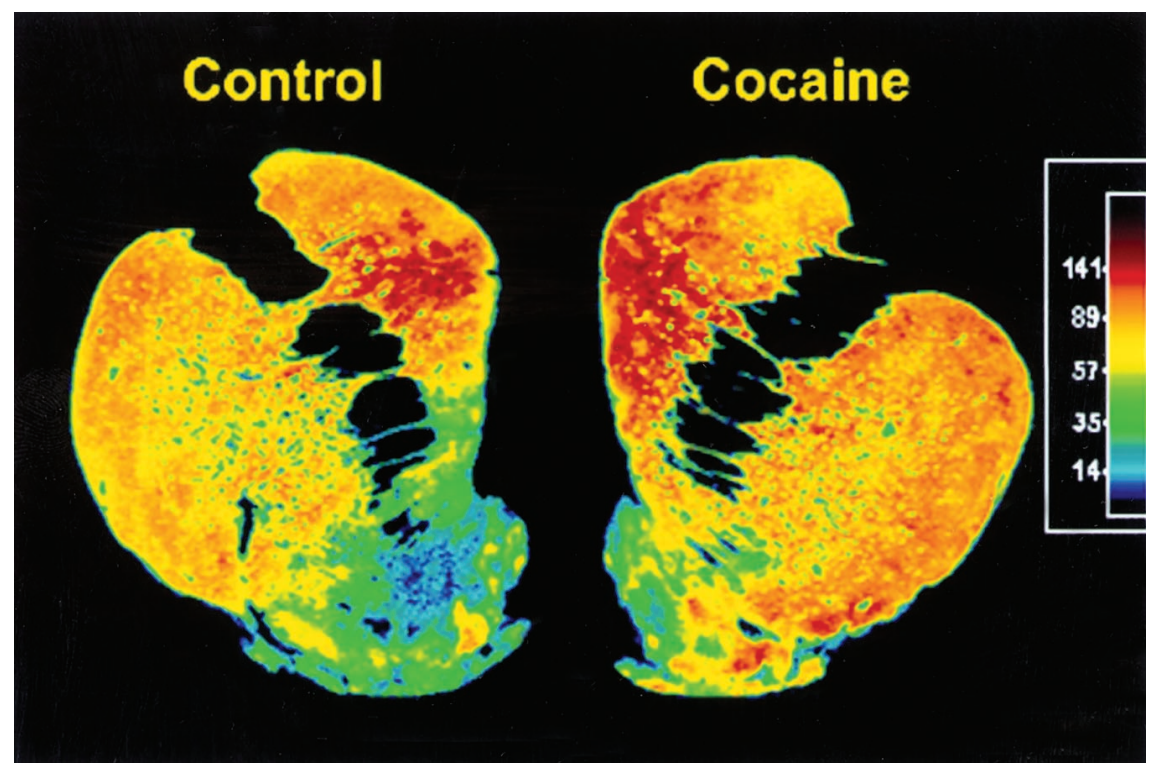

Figure 4. Representative autroadiograms from control and long-term self-administering monkeys. Color-coded transformations of autoradiograms of $\left[{ }^{3} \mathrm{H}\right]$ WIN 35,428 binding sites in coronal sections through the caudal PCS from a control (left) and long-term cocaine self-administering (right) monkey. Each color represents a range of values expressed as femtomoles per milligram wet weight tissue. Higher levels of $\left[{ }^{3} \mathrm{H}\right]$ W IN 35,428 binding are seen throughout the striatum of the long-term self-administering monkey. 
DAT binding sites are results of post-translational events such as glycosylation or phosphorylation. Nonetheless, cocaine binds to the same site as $\left[{ }^{3} \mathrm{H}\right]$ WIN 35,425 (Kaufman et al., 1991). Therefore, changes in levels of DAT binding sites found in the present study may represent a fundamental adaptation in the dopamine system. As such, the perturbations in levels of DAT binding sites may persist even after cessation of drug intake and may mediate craving and relapse. Recent work by Volkow and colleagues (1996) indicate that, in detoxified human cocaine abusers, DAT availability returns to normal by 3 months. Studies are currently underway in our laboratory to characterize the effects of withdrawal on the DAT system in a monkey model of cocaine selfadministration, similar to the one used in the present study.

\section{REFERENCES}

Alburges ME, Narang N, Wamsley JK (1993) Alterations in the dopaminergic receptor system after chronic administration of cocaine. Synapse 14:314-323.

Allard P, Eriksson K, Ross SB, Marcusson JO (1990) Unaltered $\left[{ }^{3} \mathrm{H}\right]$ GBR-12935 binding after chronic treatment with dopamine active drugs. Psychopharmacology 102:291-294.

Benmansour S, Tejani-Butt SM, Hauptmann M, Brunswick DJ (1992) Lack of effect of high-dose cocaine on monoamine uptake sites in rat brain measured by quantitative autoradiography. Psychopharmacology 106:459-462.

Boulay D, Duterte-Boucher D, Leroux-Nicollet I, Naudon L, Costentin J (1996) Locomotor sensitization and decrease in $\left[{ }^{3} \mathrm{H}\right]$ mazindol binding to the dopamine transporter in the nucleus accumbens are delayed after chronic treatments by GBR12783 or cocaine. J Pharmacol Exp Ther 278:330-337.

Bradberry CW (2000) Acute and chronic dopamine dynamics in a nonhuman primate model of recreational cocaine use. J Neurosci 20:7109-7115.

Bradberry CW, Barrett-Larimore RL, Jatlow P, Rubino SR (2000) Impact of self-administered cocaine and cocaine cues on extracellular dopamine in mesolimbic and sensorimotor striatum in rhesus monkeys. J Neurosci 20:3847-3883.

Canfield DR, Spealman RD, Kaufman MJ, Madras BK (1990) Autoradiographic localization of cocaine binding sites by $\left[{ }^{3} \mathrm{H}\right] \mathrm{CFT}\left(\left[{ }^{3} \mathrm{H}\right] \mathrm{WIN}\right.$ 35,428 ) in the monkey brain. Synapse 6:189-195.

Cass WA, Gerhardt GA, Gillespie K, Curella P, Mayfield RD, Zahniser NR (1993) Reduced clearance of exogenous dopamine in rat nucleus accumbens, but not in dorsal striatum, following cocaine challenge in rats withdrawn from repeated cocaine administration. J Neurochem 61:273-283.

Claye LH, Akunne HC, Davis MD, Demattos S, Soliman KF (1995) Behavioral and neurochemical changes in the dopaminergic system after repeated cocaine administration. Mol Neurobiol 11:55-66.

Daunais JB, Lyons D, Nader MA, Friedman DP, Porrino LP (1997) Heterogeneity of local rates of cerebral metabolism in the primate striatum. Soc Neurosci Abstr 23:803.

De La Garza R, Meltzer PC, Madras BK (1999) Non-amine dopamine transporter probe $\left[{ }^{3} \mathrm{H}\right]$ tropoxene distributes to dopamine-rich regions of monkey brain. Synapse 34:20-27.

De Wit H, Wise RA (1977) Blockade of cocaine reinforcement in rats with the dopamine blocker, pimozide, but not with the noradrenergic blockers phentolamine or phenoxybenzamine. Can J Psychol 31:195-203.

Drevets WC, Price JC, Kupfer DJ, Kinahan PE, Lopresti B, Holt D, Mathis C (1999) PET measures of amphetamine-induced release in ventral versus dorsal striatum. Neurophychopharmacology 21:694-709.

Farfel GM, Kleven MS, Woolverton WL, Seiden LS, Perry BD (1992) Effects of repeated injections of cocaine on catecholamine receptor binding sites, dopamine transporter binding sites and behavior in rhesus monkey. Brain Res 578:235-243.

Gawin F (1991) Cocaine addiction: psychology and neurophysiology. Science 251:1580-1589.

Giros B, Jaber M, Jones SR, Wightman RM, Caron MG (1996) Hyperlocomotion and indifference to cocaine and amphetamine in mice lacking the dopamine transporter. Nature 379:606-612.

Goeders NE, Smith JE (1983) Cortical dopaminergic involvement in cocaine reinforcement. Science 221:773-775.

Graybiel AM, Moratalla R (1989) Dopamine uptake sites in the striatum are distributed differentially in striosome and matrix compartments. Proc Natl Acad Sci USA 86:9020-9024.

Hitri A, Little KY, Ellinwod EH (1996) Effect of cocaine on dopamine transporter receptors depends on routes of chronic cocaine administration. Neuropsychopharmacology 14:205-210.
Hurd YL, Herkenham M (1993) Molecular alterations in the neostriatum of human cocaine addicts. Synapse 13:357-369.

Iglauer C, Woods JH (1974) Concurrent performances: reinforcement by different doses of intravenous cocaine in rhesus monkeys. J Exp Anal Behav 22:179-196.

Kaufman MJ, Spealman RD, Madras BK (1991) Distribution of cocaine recognition sites in monkey brain. I. In vitro autoradiography with $\left[{ }^{3} \mathrm{H}\right] \mathrm{CFT}$. Synapse 9:177-187.

Kennedy LT, Hanbauer I (1983) Sodium-sensitive cocaine binding to rat striatal membrane: possible relationship to dopamine uptake sites. J Neurochem 41:172-178.

Koe BK (1976) Molecular geometry of inhibitors of the uptake of catecholamines and serotonin in synaptosomal preparations of rat brain. J Pharmacol Exp Ther 199:649-661.

Kula NS, Baldessarini RJ (1991) Lack of increase in dopamine transporter binding of function in rat brain tissue after treatment with blockers of neuronal uptake of dopamine. Neuropharmacology 30:89-92.

Kunko PM, Loeloff RJ, Izenwasser S (1997) Chronic administration of the selective dopamine uptake inhibitor GBR 12909, but not cocaine, produces marked decreases in dopamine transporter density. Naunyn Schmiedebergs Arch Pharmacol 356:562-569.

Letchworth SR, Daunais JB, Hedgecock AA, Porrino LJ (1997) Effects of chronic cocaine administration on dopamine transporter mRNA and protein in the rat. Brain Res 750:214-222.

Letchworth SR, Sexton T, Childers SR, Vrana KE, Vaughn RA, Davies HML, Porrino LJ (1999) Regulation of rat dopamine transporter mRNA and protein by chronic cocaine administration. J Neurochem 73:1982-1989.

Little KY, Kirkman JA, Carroll FI, Clark TB, Duncan GE (1993) Cocaine use increases $\left[{ }^{3} \mathrm{H}\right]$ W IN 35428 binding sites in human striatum. Brain Res 628:17-25.

Little KY, Carroll FI, Buts JD (1998a) Striatal [ ${ }^{125}$ I]RTI-55 binding sites in cocaine-abusing humans. Prog Neuropsychopharmacol Biol Psychiatry 22:455-466.

Little KY, McLaughlin DP, Zhang L, McFinton PR, Dalak GW, Cook EH, Cassin BJ, Watson SJ (1998b) Brain dopamine transporter messenger RNA and binding sites in cocaine users: a postmortem study. Arch Gen Psychiatry 55:793-799.

Little KY, Zhang L, Desmond T, Frey KA, Dalack GW, Cassin BJ (1999) Striatal dopaminergic abnormalities in human cocaine users. Am J Psychiatry 156:238-245.

Malison RT, Best SE, van Dyck CH, McCane EF, Wallace EA, Laruelle M, Baldwin RM, Seibyl JP, Price LH, Kosten TR, Innis RB (1998) Elevated striatal dopamine transporters during acute cocaine abstinence as measured by $\left[{ }^{123} \mathrm{I}\right] \beta-\mathrm{CIT}$ SPECT. Am J Psychiatry 155:832-834.

Moore RJ, Vinsant SL, Nader MA, Porrino LJ, Friedman DP (1998) Effect of cocaine self-administration on striatal dopamine $D_{1}$ receptors in rhesus monkeys. Synapse 28:1-9.

Nader MA, Bowen CA (1995) Effects of different food-reinforcement histories on cocaine self-administration by rhesus monkeys. Psychopharmacology 118:287-294.

Nader MA, Reboussin DM (1994) The effects of behavioral history on cocaine self-administration by rhesus monkeys. Psychopharmacology 115:53-58.

Oakman S, Zhang L, Maddox R, Little KY (2000) Cocaine effects on striatal dopamine transporter (DAT) and vesicular monoamine transporter (VMAT2) protein in humans. Biol Psychiatry 47:130.S.

Pilotte NS, Sharpe LG, Kuhar MJ (1994) Withdrawal of repeated intravenous infusions of cocaine persistently reduces binding to dopamine transporters in the nucleus accumbens of Lewis rats. J Pharmacol Exp Ther 269:963-969.

Pilotte NS, Sharpe LG, Rountree SD, Kuhar MJ (1996) Cocaine withdrawal reduces dopamine transporter binding in the shell of the nucleus accumbens. Synapse 22:87-92.

Ritz MC, Lamb RJ, Goldberg SR, Kuhar MJ (1987) Cocaine receptors on dopamine transporters are related to self-administration of cocaine. Science 237:1219-1223.

Ritz MC, Cone EJ, Kuhar MJ (1990) Cocaine inhibition of ligand binding at dopamine, norepinephrine and serotonin transporters: a structure-activity study. Life Sci 46:635-645.

Roberts DCS, Koob GF, Klonoff P, Fibiger HC (1980) Extinction and recovery of cocaine self-administration following 6-hydroxydopamine lesions of the nucleus accumbens. Pharmacol Biochem Behav 12:781-787.

Ross SB, Renyi AL (1967) Inhibition of the uptake of tritiated catecholamines by antidepressant and related agents. Eur J Pharmacol 2:181-186.

Sharpe LG, Pilotte NS, Mitchell WM, De Souza EB (1991) Withdrawal of repeated cocaine decreases autoradiographic $\left[{ }^{3} \mathrm{H}\right]$ mazindol-labeling of dopamine transporter in rat nucleus accumbens. Eur J Pharmacol 203:141-144.

Soucy JP, Mrini A, Lafaille F, Doucet G, Descarries L (1997) Compar- 
ative evaluation of $\left[{ }^{3} \mathrm{H}\right.$ ]W IN 35428 and $\left[{ }^{3} \mathrm{H}\right]$ GBR 12935 as markers of dopamine innervation density in brain. Synapse 25:163-175.

Spealman RD, Madras BK, Bergman J (1989) Effects of cocaine and related drugs in nonhuman primates. II. Stimulant effects on scheduledcontrolled behavior. J Pharmacol Exp Ther 251:142-149.

Staley JK, Basile M, Flynn DD, Mash DC (1994a) Visualizing dopamine and serotonin transporters in the human brain with the potent cocaine analogue [ $\left.{ }^{125} \mathrm{I}\right] \mathrm{RTI}-55$ : in vitro binding and autoradiographic characterization. J Neurochem 62:549-556.

Staley JK, Hearn WL, Ruttenber AJ, Wetli CV, Mash DC (1994b) High affinity cocaine recognition sites on the dopamine transporter are elevated in fatal cocaine overdose victims. J Pharmacol Exp Ther 271:1678-1685.

Staley JK, Segal DM, Heilman CJ, Levey AI, Mash DC (1995) Quantification of dopamine transporter proteins in cocaine fatalities using immunological approaches. Soc Neurosci Abstr 21:721.

Tella SR, Ladenheim B, Andrews AM, Goldberg SR, Cadet JL (1996) Differential reinforcing effects of cocaine and GBR-12909: biochemical evidence for divergent neuroadaptive changes in the mesolimbic dopaminergic system. J Neurosci 16:7416-7427.

Volkow ND, Wang GD, Fowler JS, Logan J, Hitzemann R, Gatley SJ,
MacGregor RR, Wolf AP (1996) Cocaine uptake is decreased in the brain of detoxified cocaine abusers. Neuropsychopharmocology 14:159-168.

Volkow ND, Wang GJ, Fischman MW, Foltin RW, Fowler JS, Abumrad NN, Vitkun S, Logan J, Gatley SJ, Pappas N, Hitzemann R, Shea CE (1997) Relationship between subjective effects of cocaine and dopamine transporter occupancy. Nature 386:827-830.

Wilson JM, Nobrega JN, Carroll ME, Niznik HB, Shannak K, Lac ST, Pristupa ZB, Dixon LM, Kish SJ (1994a) Heterogeneous subregional binding patterns of ${ }^{3} \mathrm{H}$-WIN 35, 428 and ${ }^{3} \mathrm{H}$-GBR 12,935 are differentially regulated by chronic cocaine self-administration. J Neurosci 14:2966-2979.

Wilson JM, Nobrega JN, Corrigall WA, Coen KM, Shannak K, Kish SJ (1994b) Amygdala dopamine levels are markedly elevated after selfbut not passive-administration of cocaine. Brain Res 668:39-45.

Wilson JM, Levey AI, Bergeron C, Kalasinsky K, Ang L, Peretti F, Adams VI, Smialek J, Anderson WR, Shannak K, Deck J, Niznik HB, Kish SJ (1996) Striatal dopamine, dopamine transporter, and vesicular monoamine transporter in chronic cocaine users. Ann Neurol 40: $428-439$. 